\title{
Antimicrobial Activity of Cladonia verticillaris Lichen Preparations on Bacteria and Fungi of Medical Importance
}

\author{
Dalila de Brito Marques Ramos, ${ }^{1}$ Francis Soares Gomes, ${ }^{1}$ \\ Thiago Henrique Napoleão, ${ }^{1}$ Patrícia Maria Guedes Paiva, ${ }^{1}$ \\ Michele Dalvina Correia da Silva, ${ }^{2}$ and Luana Cassandra Breitenbach Barroso Coelho ${ }^{1}$ \\ ${ }^{1}$ Departamento de Bioquímica, CCB, Universidade Federal de Pernambuco, Avenida Professor Moraes Rego $s / n$, \\ Cidade Universitária, 50670-420 Recife, PE, Brazil \\ ${ }^{2}$ Departamento de Ciências Animais, Universidade Federal Rural do Semi-Árido, 59625-900 Mossoró, RN, Brazil
}

Correspondence should be addressed to Luana Cassandra Breitenbach Barroso Coelho; lcbbcoelho@gmail.com

Received 22 October 2013; Accepted 27 November 2013; Published 22 January 2014

Academic Editors: B. Martinac and Z. Qiusheng

Copyright (C) 2014 Dalila de Brito Marques Ramos et al. This is an open access article distributed under the Creative Commons Attribution License, which permits unrestricted use, distribution, and reproduction in any medium, provided the original work is properly cited.

\begin{abstract}
Cladonia verticillaris lichen lectin (ClaveLL) was purified using a previously established protocol and then evaluated for its potential antimicrobial activity. Initially, the autochthonous lichen was submitted to extraction with sodium phosphate buffer pH 7.0, followed by filtration and centrifugation to obtain crude extract. A salt fractionation was performed with $30 \%$ ammonium sulfate. After centrifugation, the protein fraction was loaded onto molecular exclusion chromatography using Sephadex G-100 matrix to purify active lectin. ClaveLL showed antibacterial activity against Gram-positive (Bacillus subtilis, Staphylococcus aureus, and Enterococcus faecalis) and Gram-negative (Escherichia coli and Klebsiella pneumoniae) assayed strains, with greater inhibitory effect on growth of E. coli (MIC of $7.18 \mu \mathrm{g} \mathrm{mL}^{-1}$ ). The lowest minimum bactericidal concentration (MBC, $57.4 \mu \mathrm{g} \mathrm{mL}^{-1}$ ) was detected against $E$. faecalis. The antifungal assay performed with Trichophyton mentagrophytes, Microsporum gypseum, Trichophyton rubrum, Trichosporon cutaneum, and Trichosporon asahi evaluated crude extract, fraction, and ClaveLL preparations. ClaveLL was the most active against T. rubrum with an inhibition percentage of $35 \%$ compared to negative control (phosphate buffer). Extract and fraction showed better activity on growth inhibition of T. mentagrophytes (35\%). The results indicate the potential of ClaveLL and other C. verticillaris preparations as antimicrobial agents useful for applications focusing on human health.
\end{abstract}

\section{Introduction}

The treatment of diseases caused by bacteria and fungi is becoming an issue of concern, due to the growing emergence of microorganism strains resistant to drugs and opportunistic fungi that cause serious infections in humans $[1,2]$. Microbial resistance is a genetic phenomenon, in which the microorganisms have genes that encode biochemical mechanisms which prevent drug actions. It may be caused by mutations in the reproductive process of the microorganisms or by imported genes acquired through transduction, conjugation, and transformation mechanisms [3]. Microbial resistance is sometimes due to natural evolution of microorganisms; however, it gains importance through the excessive use of antimicrobial substances in medical, agricultural, and veterinary practices [4]. Therefore, the search for new antibiotics from natural sources has increased as an alternative to commercial drugs.

Lichens are symbiotic associations between fungus and one or more algae and/or cyanobacteria [5]. Species of the genus Cladonia have been used in folk medicine to treat respiratory diseases such as throat irritation, cough, asthma, and tuberculosis $[6,7]$. The use of lichens in medicine is based on the fact that they contain unique and various biologically active substances, mainly with antimicrobial actions $[8,9]$. Cladonia verticillaris is a lichen of cosmopolitan distribution 
and represents a rich source of lectin (carbohydrate-binding protein). The protocol established for isolation of C. verticillaris lichen lectin (ClaveLL) is simple and yields milligram quantities of protein (18 mg from $20 \mathrm{~g}$ of lichen flour) free of secondary metabolites. ClaveLL showed insecticidal activity on termite Nasutitermes corniger [10].

The lichen $C$. verticillaris produces bioactive secondary metabolites, such as fumarprotocetraric and protocetraric acids. The fumarprotocetraric acid has demonstrated biological actions, such as expectorant, antioxidant, and allelopathic effect [11, 12]. However, little has been done with respect to lichen lectins and their biological properties and potential biotechnological applications.

Lectins with potential for biotechnological applications as antibiotics have been isolated and their structures have been characterized [13-15]. Lectins are a heterogeneous group of proteins from no immune origin, containing two or more binding sites for mono or oligosaccharides [16]. Gomes et al. [17] isolated a lectin from leaves of Schinus terebinthifolius that showed antibacterial activity against human pathogenic bacteria and the fungus Candida albicans. Besides being applied to control bacteria and fungi growth, lectins can be used for detection and typing of microorganisms due to the selective interaction between lectins and microorganisms [18].

Fungi known as dermatophytes of the genus Trichophyton and Microsporum cause superficial mycoses affecting the hair, nails, and skin. Trichosporon species have contributed to increased mortality in immunocompromised individuals [19]. Thus, the aim of this study was to evaluate the antimicrobial activity of purified $C$. verticillaris lichen lectin (ClaveLL) against human pathogenic bacteria Gram-positive (Bacillus subtilis, Staphylococcus aureus, Enterococcus faecalis, Escherichia coli, and Klebsiella pneumoniae) as well as against dermatophyte fungi (Trichophyton mentagrophytes, Microsporum gypseum, Trichophyton rubrum, Trichosporon cutaneum, and Trichosporon asahi).

\section{Materials and Methods}

2.1. Purification of ClaveLL. C. verticillaris lichen was collected at Alhandra City, State of Paraíba in the Northeastern of Brazil, and gently identified by Dr. Eugênia Cristina Gonçalves Pereira (Departamento de Ciências Geográficas, Centro de Filosofia e Ciências Humanas, UFPE). C. verticillaris lichen lectin (ClaveLL) was obtained through a sequential purification protocol according to Silva et al. [10]. Lichen was dried at $28^{\circ} \mathrm{C}$ and an overnight extraction $(10 \%$, w/v) for $16 \mathrm{~h}$ at $28^{\circ} \mathrm{C}$ was performed in $0.15 \mathrm{M}$ sodium phosphate buffer $\mathrm{pH} 7.0$ containing $0.15 \mathrm{M} \mathrm{NaCl}$ (PBS), followed by filtration and centrifugation $\left(3000 \mathrm{~g}, 4^{\circ} \mathrm{C}, 15 \mathrm{~min}\right)$. The lichen extract was treated with $30 \%(\mathrm{w} / \mathrm{v})$ ammonium sulphate for $4 \mathrm{~h}$ at $28^{\circ} \mathrm{C}$. The $0-30 \%$ precipitate fraction was obtained by centrifugation $\left(3000 \mathrm{~g}, 4^{\circ} \mathrm{C}, 15 \mathrm{~min}\right)$, dialyzed for salt removal, submitted to protein quantification, and loaded $(18 \mathrm{mg}$ of protein) onto a gel filtration chromatography containing $100 \mathrm{~mL}$ of Sephadex G-100 $(1.4 \times 63 \mathrm{~cm})$. The molecular exclusion column was performed using with PBS at a flow rate of $20 \mathrm{~mL} / \mathrm{h}$. The collected fractions were monitored for absorbance at $280 \mathrm{~nm}$ and hemagglutinating activity.

2.2. Hemagglutinating Activity. Hemagglutinating activity was determined according to method described by Correia et al. [20]. The sample $(50 \mu \mathrm{L})$ was twofold serially diluted in $0.15 \mathrm{M} \mathrm{NaCl}$ on microplate wells. Next, a suspension of $2.5 \%$ glutaraldehyde-treated rabbit erythrocytes [21] was added $(50 \mu \mathrm{L})$ to each well. One hemagglutination unit (titer ${ }^{-1}$ ) was defined as the reciprocal of the highest sample dilution which promoted full erythrocyte agglutination. Specific hemagglutinating activity was defined as the ratio between the titer and protein concentration $\left(\mathrm{mg} \cdot \mathrm{mL}^{-1}\right)$.

2.3. Protein Content. Protein concentration was determined according to Lowry et al. [22] using bovine serum albumin as standard (31.25-500 $\left.\mu \mathrm{g} \mathrm{mL}^{-1}\right)$.

2.4. Antibacterial Activity. Gram-positive (Bacillus subtilis ATCC-6633, Staphylococcus aureus ATCC-6538 and Enterococcus faecalis ATCC-6057), and Gram-negative (Escherichia coli ATCC-25922 and Klebsiella pneumoniae ATCC-29665) bacterial strains were provided by the Departamento de Antibióticos, Universidade Federal de Pernambuco, Brazil. Stationary cultures were maintained in nutrient agar (NA) and stored at $4^{\circ} \mathrm{C}$. Bacteria were cultured in nutrient broth (NB) and incubated under permanent shaking at $37^{\circ} \mathrm{C}$ overnight. The culture concentrations were adjusted turbidimetrically at a wavelength of $490 \mathrm{~nm}$ to $10^{5}-10^{6}$ colony forming units (CFU) $\cdot \mathrm{mL}^{-1}$.

An aliquot of ClaveLL $(100 \mu \mathrm{L} ; 0.184 \mu \mathrm{g})$ was diluted $1: 1$ in NB and then submitted to a series of ten double dilutions, until a final ratio of $1: 2048$. Next, a $180 \mu \mathrm{L}$ aliquot of each dilution was dispensed into each well of a 96-well microplate. All wells were inoculated with $20 \mu \mathrm{L}$ of the bacterial culture and incubated at $37^{\circ} \mathrm{C}$ for $24 \mathrm{~h}$. Assay for each concentration was performed in triplicate. Control wells contained only NB medium and microorganism. After incubation, the optical density at $490 \mathrm{~nm}\left(\mathrm{OD}_{490}\right)$ was measured using a microplate reader. Minimal inhibitory concentration (MIC) was determined as the lowest lectin concentration at which there was $\geq 50 \%$ reduction in OD490 in comparison with the control [23].

To determine the minimal bactericidal concentration (MBC), inoculations $(10 \mu \mathrm{L})$ from the sample wells at which inhibition of bacterial growth was detected were transferred to NA plates and incubated at $37^{\circ} \mathrm{C}$ for $24 \mathrm{~h}$. The MBC corresponded to the lowest sample concentration at which no bacterial growth was observed. The assay was performed in triplicate.

2.5. Antifungal Activity. Trichophyton mentagrophytes (URM5541), Microsporum gypseum (URM6199), Trichophyton rubrum (URM5145), Trichosporon cutaneum (URM5743), and Trichosporon asahi (URM5781) were obtained from the Cultures Collection of University Recife Mycologia (URM) from the Departamento de Micologia of the Universidade 
TABLE 1: Summary of ClaveLL purification.

\begin{tabular}{lccccc}
\hline Sample & Volume $(\mathrm{mL})$ & Protein $(\mathrm{mg} / \mathrm{mL})$ & HA $^{\mathrm{a}}$ & SHA $^{\mathrm{b}}(\mathrm{HA} / \mathrm{mg})$ & Purification fold $^{\mathrm{c}}$ \\
\hline Lichen extract & 430 & 9.4 & 512 & 54.3 & 1.0 \\
0-30\% fraction & 18 & 40.4 & 16384 & 405 & 7.5 \\
ClaveLL & 396 & 0.1 & 64 & 711 & 13.1 \\
\hline
\end{tabular}

${ }^{a}$ HA: hemagglutinating activity; ${ }^{b}$ SHA: specific HA; ${ }^{c}$ purification fold: relation between SHA of crude extract and SHA of lectin.

TABLE 2: MIC and MBC of ClaveLL against bacteria species.

\begin{tabular}{lcc}
\hline Microorganisms & $\left.\mathrm{MIC}(\mu \mathrm{g} \mathrm{mL})^{-1}\right)$ & $\mathrm{MBC}^{\left(\mu \mathrm{g} \mathrm{mL} L^{-1}\right)}$ \\
\hline Staphylococcus aureus $(+)$ & 229.9 & 459.9 \\
Bacillus subtilis $(+)$ & 28 & 57.4 \\
Enterococcus faecalis $(+)$ & 28 & 57.4 \\
Klebsiella pneumoniae $(-)$ & 114.9 & 919.8 \\
Escherichia coli $(-)$ & 7.18 & 229.9 \\
\hline
\end{tabular}

Gram-positive (+) and Gram-negative (-) bacteria; MIC: minimum inhibitory concentration. MBC: minimum bactericidal concentration.

Federal of Pernambuco (UFPE), Brazil. Antifungal activity was performed according to Wong and $\mathrm{Ng}$ [24] with modifications. Fungi were grown at $28^{\circ} \mathrm{C}$ on potato dextrose agar (PDA) in Petri plates for an 8-15-day period until the surfaces of the plates were completely covered by them. Fungal mycelium discs $(0.625 \mathrm{~cm}$ in diameter $)$ were removed from the peripheral part of the colonies. ClaveLL $(100 \mu \mathrm{L}$; $\left.1.67 \mathrm{mg} \mathrm{mL}^{-1}\right)$, lichen extract $\left(100 \mu \mathrm{L} ; 9.43 \mathrm{mg} \mathrm{mL}^{-1}\right)$, and $0-30 \%$ fraction $\left(100 \mu \mathrm{L} ; 40.45 \mathrm{mg} \mathrm{mL}^{-1}\right)$ were spread on solidified PDA medium in Petri plates $\left(100 \times 15 \mathrm{~mm}^{2}\right)$ and a fungal mycelium disk was disposed in the center of the Petri plates. All assays were carried out in triplicate. PBS and nystatin $(1 \mathrm{mg} / \mathrm{mL})$ were used as negative and positive controls, respectively. The plates were incubated at $28^{\circ} \mathrm{C}$ for $72 \mathrm{~h}$. Antifungal activity was indicated by reduction of the fungal growth zone (diameter) in the plates.

2.6. Statistical Analysis. Standard deviations (SD) were calculated using GraphPad Prism version 4.0 for Windows (GraphPad Software, San Diego, CA, USA) and data were expressed as a mean of replicates \pm SD. Significant differences between treatment groups from the antifungal assays were analysed by Student's $t$-test (significance at $P<0.05$ ) using the Origin 6.0 program.

\section{Results and Discussion}

Extraction and isolation of pharmacologically active compounds with medicinal importance have received attention in the search for new economically viable alternatives for treating human infections. ClaveLL was purified through a preestablished protocol by Silva et al. [10] using molecular exclusion chromatography on Sephadex G-100 matrix; the column is a viable approach since the same array can be reused efficiently at least 30 times to purify ClaveLL.

Treatment of lichen extract with ammonium sulphate yielded a precipitated protein fraction $(0-30 \%$ fraction). Chromatography of $0-30 \%$ fraction on Sephadex G-100 separated two peaks (Figure 1): the first (corresponding to fractions 7-22) was colorless and showed hemagglutinating

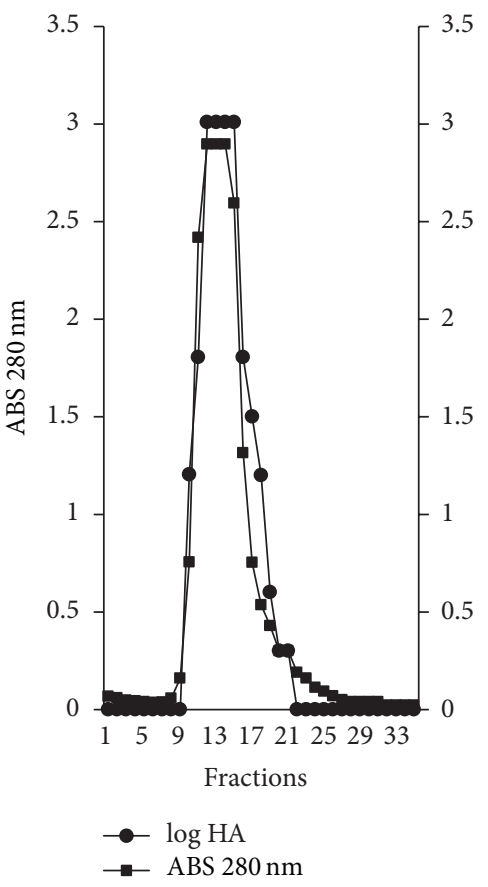

FIGURE 1: ClaveLL isolated from 0-30\% fraction through molecular exclusion chromatography using Sephadex G-100 column (HA in $\log$ scale).

activity of 64 , corresponding to ClaveLL, with a purification factor of 13.1 times (Table 1). A total of $8.28 \mathrm{mg}$ of ClaveLL were purified from $10 \mathrm{~g}$ of C. verticillaris, yield similar to that obtained by Silva et al. [10]. The second peak showed a strong color similar to the fraction and did not show hemagglutinating activity.

ClaveLL revealed antibacterial activity against all tested species, both Gram-positive and Gram-negative. The values for MIC and MBC are shown in Table 2. The antibacterial activity of lectins may occur through the interaction with $\mathrm{N}$-acetylglucosamine (GlcNAc), $\mathrm{N}$-acetylmuramic acid (MurNAc), and tetrapeptides linked to MurNAc present in 


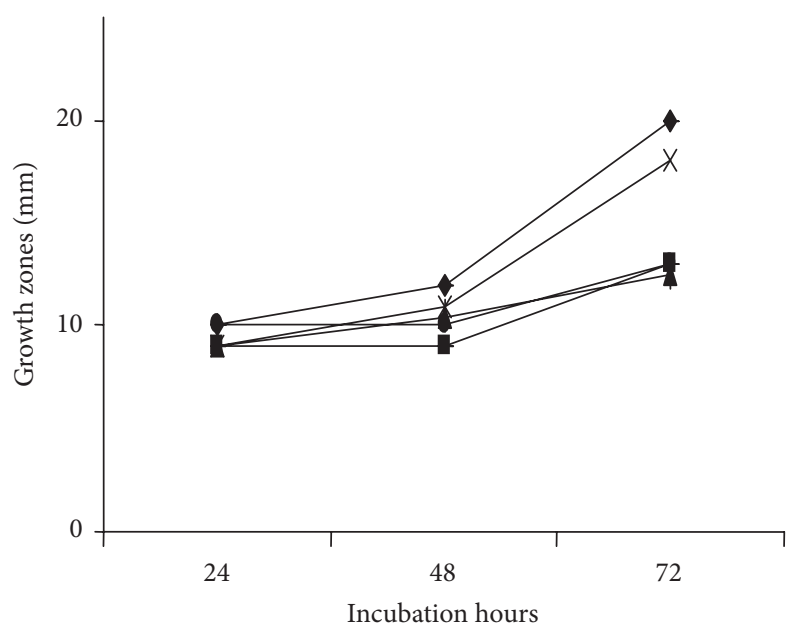

(a)

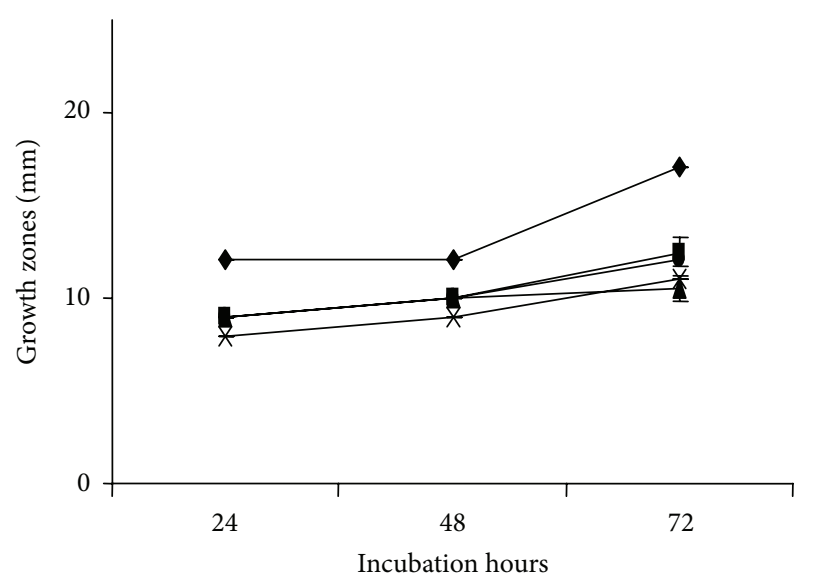

(c)

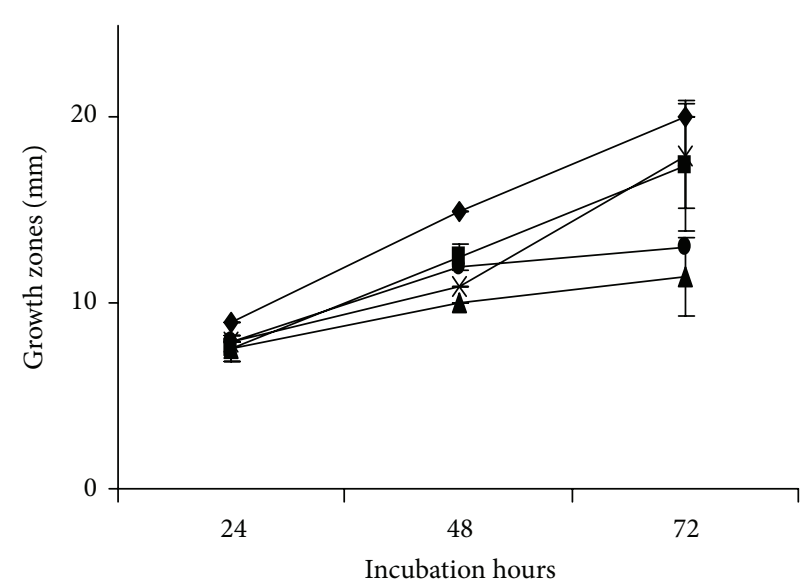

(b)

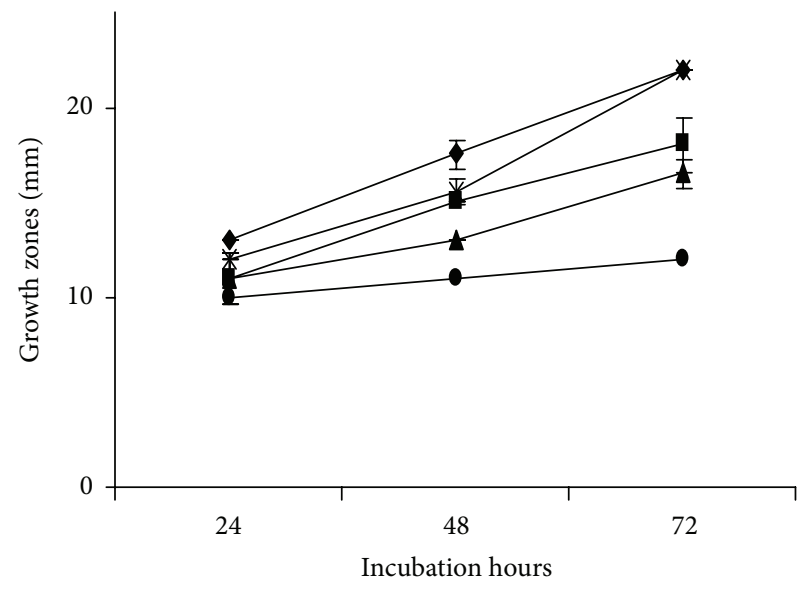

(d)

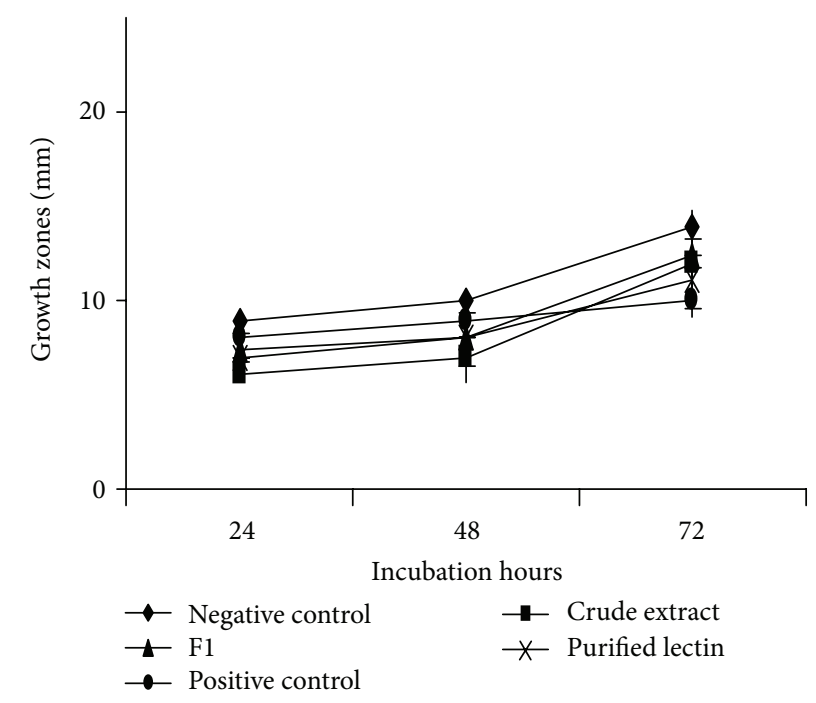

(e)

Figure 2: Growth zones (mm) of the fungi T. mentagrophytes (a), M. gypseum (b), T. rubrum (c), T. cutaneum (d), and T. asahi (e) in PDA medium ( $y$-axis) throughout the incubation hours. Each point represents the mean \pm SD of three experiments. 


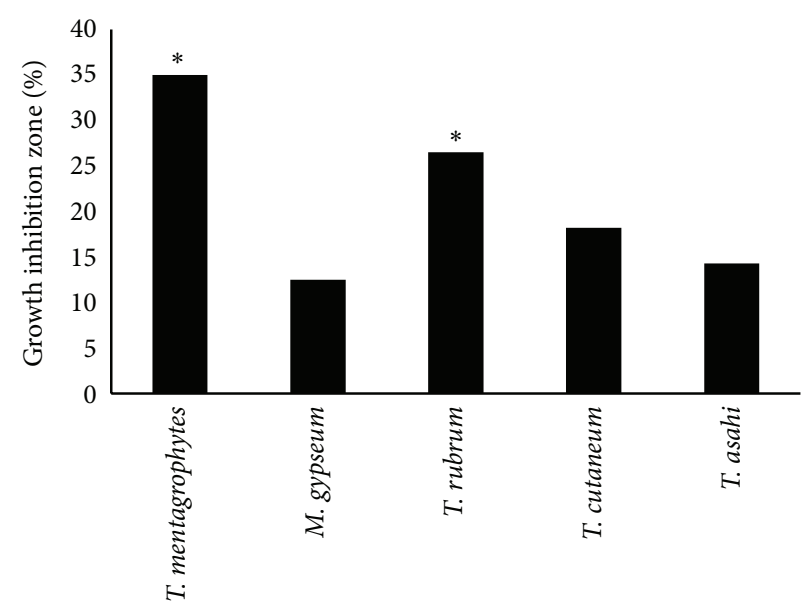

(a)

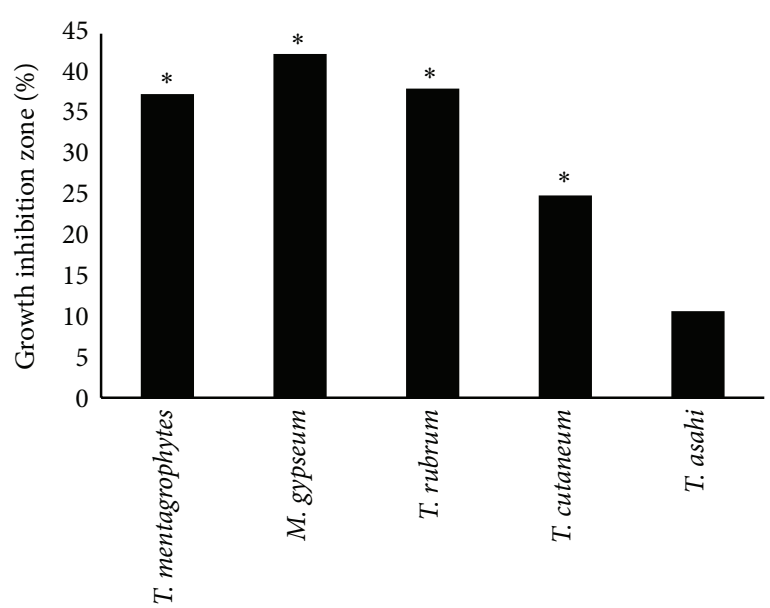

(b)

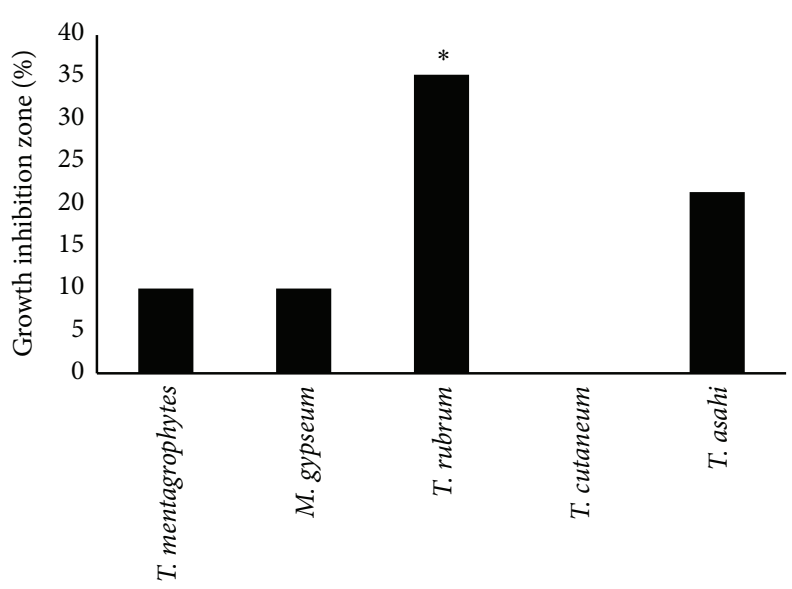

(c)

FIGURE 3: Antifungal activity of lichen extract (a), 0-30\% fraction (b), and ClaveLL (c) observed as percentage of growth inhibition in comparison with growth in control. The histograms representing average values of tree measurement of inhibition zones. The $*$ indicates significant differences between treatments and control.

the cell wall of Gram-positive bacteria or to lipopolysaccharide present in the cell walls of Gram-negative bacteria [25].

Among the bacteria tested, ClaveLL showed the best inhibitory activity against the Gram-negative bacteria $E$. coli with MIC value of $7.18 \mu \mathrm{g} \mathrm{mL}^{-1}$ and the best bactericidal activity against Gram-positive bacteria $B$. subtilis and $E$. faecalis with MBC value of $57.4 \mu \mathrm{g} \mathrm{m}^{-1}$. Thus, ClaveLL was more efficient in killing Gram-positive than Gram-negative bacteria. Similarly, the isolated lectin from leaves of S. terebinthifolius was more efficient against the Gram-positive Staph. aureus than Gram-negative bacteria such as E. coli, Klebsiella pneumoniae, Pseudomonas aeruginosa, and Salmonella enteritidis [17]. The difference in the susceptibility of Gram-positive and Gram-negative bacteria may be linked to the difficulty of lectins to cross the Gram-negative bacteria outer cell wall to reach the periplasmic space [15]. Additionally, the high level of peptidoglycan (which contains GlcNac) in the cell wall of Gram-positive bacteria may provide more interaction sites for N-acetyl-glucosamine-binding lectins, such as ClaveLL [10].

Costa et al. [14] studied the leaf lectin of Phthirusa pyrifolia (PpyLL) and found MBC of approximately 10 times higher $\left(500 \mu \mathrm{g} \mathrm{mL}^{-1}\right)$ than ClaveLL for B. subtilis. Instead, Sá et al. [13] found MIC of $2.34 \mu \mathrm{g} \mathrm{mL}^{-1}$ of the Myracrodruon urundeuva heartwood lectin (MuHL) for this same bacterium, corresponding to a concentration 10 times lower than that of ClaveLL $\left(28 \mu \mathrm{g} \mathrm{mL}^{-1}\right)$.

Although several lectins purified from various natural sources have shown antibacterial activity [14, 26-28], its mechanism of action was not elucidated in detail. It has been proposed that lectins with antibacterial activity form pores in the cell membrane and cell dies as a result of a outflowing of cellular contents $[29,30]$.

The lichen extract (Figure 2(a)) inhibited the growth of T. mentagrophytes (35\%), fungus that was not inhibited by ClaveLL, revealing that the antimicrobial activity of 
C. verticillaris involves more than one active principle which was removed during lectin purification protocol. Perry et al. [31], studying the antimicrobial activity of 69 species of lichens from New Zealand, found that Cladonia fimbriata extract also inhibited the growth of T. mentagrophytes.

The $0-30 \%$ fraction was the sample that showed the highest antifungal activity (Figures 2 and 3), inhibiting growth of T. mentagrophytes (37.5\%), M. gypseum (42.5\%), T. rubrum (38.2\%), and T. cutaneum (25\%).

ClaveLL showed highest antifungal activity against $T$. rubrum (35.3\% of inhibition) (Figures 2 and 3). However, ClaveLL $(170 \mu \mathrm{g})$ was not active against $T$. mentagrophytes, $M$. gypseum, and T. cutaneum (Figures 2 and 3). The inhibition of fungi growth can occur through lectin binding to hyphae resulting in poor absorption of nutrients as well as by interference on spore germination process [13]. Antifungal activity of lectins is related to their property to bind carbohydrates such as chitin, a large polymer of $\mathrm{N}$-acetyl-glucosamine, and component of fungal cell wall [20]. The binding of $\mathrm{N}$-acetylglucosamine-binding lectins can lead to rupture of the fungal cell wall [32].

The antibacterial and antifungal activities of extract, 0$30 \%$ fraction, and ClaveLL are not correlated with secondary metabolites since Silva et al. [10] showed that all these preparations were absent from this class of compounds. The antifungal activity detected for extract and fraction from $C$. verticillaris encourages further studies to isolate other lichen compounds to find the chemical constituents responsible for such activity.

\section{Conclusion}

In conclusion, the lectin purified from C. verticillaris showed antibacterial activity, particularly against Gram-positive bacteria; also, it was able to inhibit the growth of the dermatophyte fungus T. rubrum. ClaveLL and other C. verticillaris preparations are potential antimicrobial agents to be applied for treating human infections.

\section{Conflict of Interests}

The authors declare that there is no conflict of interests regarding the publication of this paper.

\section{Acknowledgments}

The authors express their gratitude to the Conselho Nacional de Desenvolvimento Científico e Tecnológico (CNPq) for research grants and fellowships (PMGP and LCBBC). The authors are also grateful to the Fundação de Amparo à Ciência $e$ Tecnologia do Estado de Pernambuco (FACEPE), the Coordenação de Aperfeiçoamento de Pessoal de Nível Superior (CAPES), and the Ministério da Ciência, Tecnologia e Inovação (MCTI) for financial support. The authors thank Maria Barbosa Reis da Silva for technical assistance.

\section{References}

[1] D. Marchaim, L. Lemanek, S. Bheemreddy, K. S. Kaye, and J. D. Sobel, "Fluconazole-resistant Candida albicans vulvovaginitis," Obstetrics \& Gynecology, vol. 120, pp. 1407-1414, 2012.

[2] N. H. Yim, Y. P. Jung, W. K. Cho et al., "Screening of aqueous extracts of medicinal herbs for antimicrobial activity against oral bacteria," Integrative Medicine Research, vol. 2, no. 1, pp. 1824, 2013.

[3] J. Davies and D. Davies, "Origins and evolution of antibiotic resistance," Microbiology and Molecular Biology Reviews, vol. 74, no. 3, pp. 417-433, 2010.

[4] P. Srivastava, D. K. Upreti, T. N. Dhole, A. K. Srivastava, and M. T. Nayak, "Antimicrobial property of extracts of Indian lichen against human pathogenic bacteria," Interdisciplinary Perspectives on Infectious Diseases, vol. 2013, Article ID 709348, 6 pages, 2013.

[5] U. Kaasalainen, D. P. Fewer, J. Jokela, M. Wahlsten, K. Sivonen, and J. Rikkinen, "Cyanobacteria produce a high variety of hepatotoxic peptides in lichen symbiosis," Proceedings of the National Academy of Sciences of the United States of America, vol. 109, no. 15, pp. 5886-5891, 2012.

[6] I. Ziment, "Herbal antitussives," Pulmonary Pharmacology \& Therapeutics, vol. 15, no. 3, pp. 327-333, 2002.

[7] B. Q. Lin, P. B. Li, Y. G. Wang et al., "The expectorant activity of naringenin," Pulmonary Pharmacology \& Therapeutics, vol. 21, no. 2, pp. 259-263, 2008.

[8] N. T. Manojlovic, S. Solujic, and S. Sukdolak, "Antimicrobial activity of an extract and anthraquinones from Caloplaca schaereri," The Lichenologist, vol. 34, no. 1, pp. 83-85, 2002.

[9] M. T. Saenz, M. D. Garcia, and J. G. Rowe, "Antimicrobial activity and phytochemical studies of some lichens from south of Spain," Fitoterapia, vol. 77, no. 3, pp. 156-159, 2006.

[10] M. D. C. Silva, R. A. Sá, T. H. Napoleão et al., "Purified Cladonia verticillaris lichen lectin: insecticidal activity on Nasutitermes corniger (Isoptera: Termitidae)," International Biodeterioration \& Biodegradation, vol. 63, no. 3, pp. 334-340, 2009.

[11] A. M. Yano-Melo, C. Vicente, and L. Xavier-Filho, "Allelopathic efect of the Cladonia verticillaris lichen extracts and fumarprotocetraric acid on the early growth of germinated seedlings in Allium cepa L.”' Tropical Bryology, vol. 17, pp. 133-139, 1999.

[12] G. M. B. Alves, M. B. S. Maia, E. S. Franco et al., "Expectorant and antioxidant activities of purified fumarprotocetraric acid from Cladonia verticillaris lichen in mice," Pulmonary Pharmacology \& Therapeutics, 2013.

[13] R. A. Sá, F. S. Gomes, T. H. Napoleão et al., "Antibacterial and antifungal activities of Myracrodruon urundeuva heartwood," Wood Science and Technology, vol. 43, no. 1-2, pp. 85-95, 2009.

[14] R. M. P. B. Costa, A. F. M. Vaz, M. L. V. Oliva, L. C. B. B. Coelho, M. T. S. Correia, and M. G. Carneiro-da-Cunha, "A new mistletoe Phthirusa pyrifolia leaf lectin with antimicrobial properties," Process Biochemistry, vol. 45, no. 4, pp. 526-533, 2010.

[15] E. D. S. Nunes, M. A. A. Souza, A. F. D. M. Vaz et al., "Purification of a lectin with antibacterial activity from Bothrops leucurus snake venom," Comparative Biochemistry and Physiology B, vol. 159, no. 1, pp. 57-63, 2011.

[16] P. M. G. Paiva, E. V. Pontual, T. H. Napoleão, and L. C. B. B. Coelho, "Effects of plant lectins and trypsin inhibitors on development, morphology and biochemistry of insect larvae," in Larvae: Morphology, Biology and Life Cycle, Nova Science, New York, NY, USA, 2012. 
[17] F. S. Gomes, T. F. Procópio, T. H. Napoleão, L. C. B. B. Coelho, and P. M. G. Paiva, "Antimicrobial lectin from Schinus terebinthifolius leaf," Journal of Applied Microbiology, vol. 114, no. 3, pp. 672-679, 2013.

[18] P. M. G. Paiva, F. S. Gomes, T. H. Napoleão, R. A. Sá, M. T. S. Correia, and L. C. B. B. Coelho, "Antimicrobial activity of secondary metabolites and lectins from plants," in Current Research, Technology and Education Topics in Applied Microbiology and Microbial Biotechnology, pp. 396-406, Formatex Research Center, Badajoz, Spain, 2010.

[19] C. Girmenia, L. Pagano, B. Martino et al., "Invasive infections caused by Trichosporon species and Geotrichum capitatum in patients with hematological malignancies: a retrospective multicenter study from Italy and review of the literature," Journal of Clinical Microbiology, vol. 43, no. 4, pp. 1818-1828, 2005.

[20] M. T. S. Correia, L. C. B. B. Coelho, and P. M. G. Paiva, "Lectins, carbohydrate recognition molecules: are they toxic?" in Recent Trends in Toxicology, Y. H. Siddique, Ed., vol. 37, pp. 47-59, Transworld Research Network, Kerala, India, 2008.

[21] D. H. Bing, J. G. Weyand, and A. B. Stavitsky, "Hemagglutination with aldehyde-fixed erythrocytes for assay of antigens and antibodies," Proceedings of the Society for Experimental Biology and Medicine, vol. 124, no. 4, pp. 1166-1170, 1967.

[22] O. H. Lowry, N. J. Rosebrough, A. L. Farr, and R. J. Randall, "Protein measurement with the Folin phenol reagent," The Journal of Biological Chemistry, vol. 193, no. 1, pp. 265-275, 1951.

[23] D. Amsterdam, "Susceptibility testing of antimicrobials in liquid media," in Antibiotics in Laboratory Medicine, V. Loman, Ed., pp. 52-111, Williams \& Wilkins, Baltimore, Md, USA, 4th edition, 1996.

[24] J. H. Wong and T. B. Ng, "Sesquin, a potent defensin-like antimicrobial peptide from ground beans with inhibitory activities toward tumor cells and HIV-1 reverse transcriptase," Peptides, vol. 26, no. 7, pp. 1120-1126, 2005.

[25] R. Dziarski, M. M. Rasenick, and D. Gupta, "Bacterial peptidoglycan binds to tubulin," Biochimica et Biophysica Acta, vol. 1524, no. 1, pp. 17-26, 2000.

[26] A. S. Riera, A. Daud, A. Gallo, S. Genta, M. Aybar, and S. Sánchez, "Antibacterial activity of lactose-binding lectins from Bufo arenarum skin," Biocell, vol. 27, no. 1, pp. 37-46, 2003.

[27] K. G. Takahashi, T. Kuroda, and K. Muroga, "Purification and antibacterial characterization of a novel isoform of the Manila clam lectin (MCL-4) from the plasma of the Manila clam, Ruditapes philippinarum," Comparative Biochemistry and Physiology $B$, vol. 150, no. 1, pp. 45-52, 2008.

[28] S. M. Kawsar, S. M. Mamun, M. S. Rahman, H. Yasumitsu, and Y. Ozeki, "In-vitro antibacterial and antifungal effects of a 30 $\mathrm{kDa}$ D-galactoside-specific lectin from the Demosponge, Halichondria okadai," International Journal of Biological Sciences, vol. 6, no. 1, pp. 31-37, 2010.

[29] T. Santi-Gadelha, C. A. A. Gadelha, K. S. Aragão et al., "Purification and biological effects of Araucaria angustifolia (Araucariaceae) seed lectin," Biochemical and Biophysical Research Communications, vol. 350, no. 4, pp. 1050-1055, 2006.

[30] M. D. L. Oliveira, C. A. S. Andrade, N. S. Magalhães et al., "Purification of a lectin from Eugenia uniflora L. seeds and its potential antibacterial activity," Letters in Applied Microbiology, vol. 46, no. 3, pp. 371-376, 2008.

[31] N. B. Perry, M. H. Benn, N. J. Brennan et al., "Antimicrobial, antiviral and cytotoxic activity of New Zealand lichens," The Lichenologist, vol. 31, no. 6, pp. 627-636, 1999.
[32] D.-J. Yun, J. I. Ibeas, H. Lee et al., "Osmotin, a plant antifungal protein, subverts signal transduction to enhance fungal cell susceptibility," Molecular Cell, vol. 1, no. 6, pp. 807-817, 1998. 

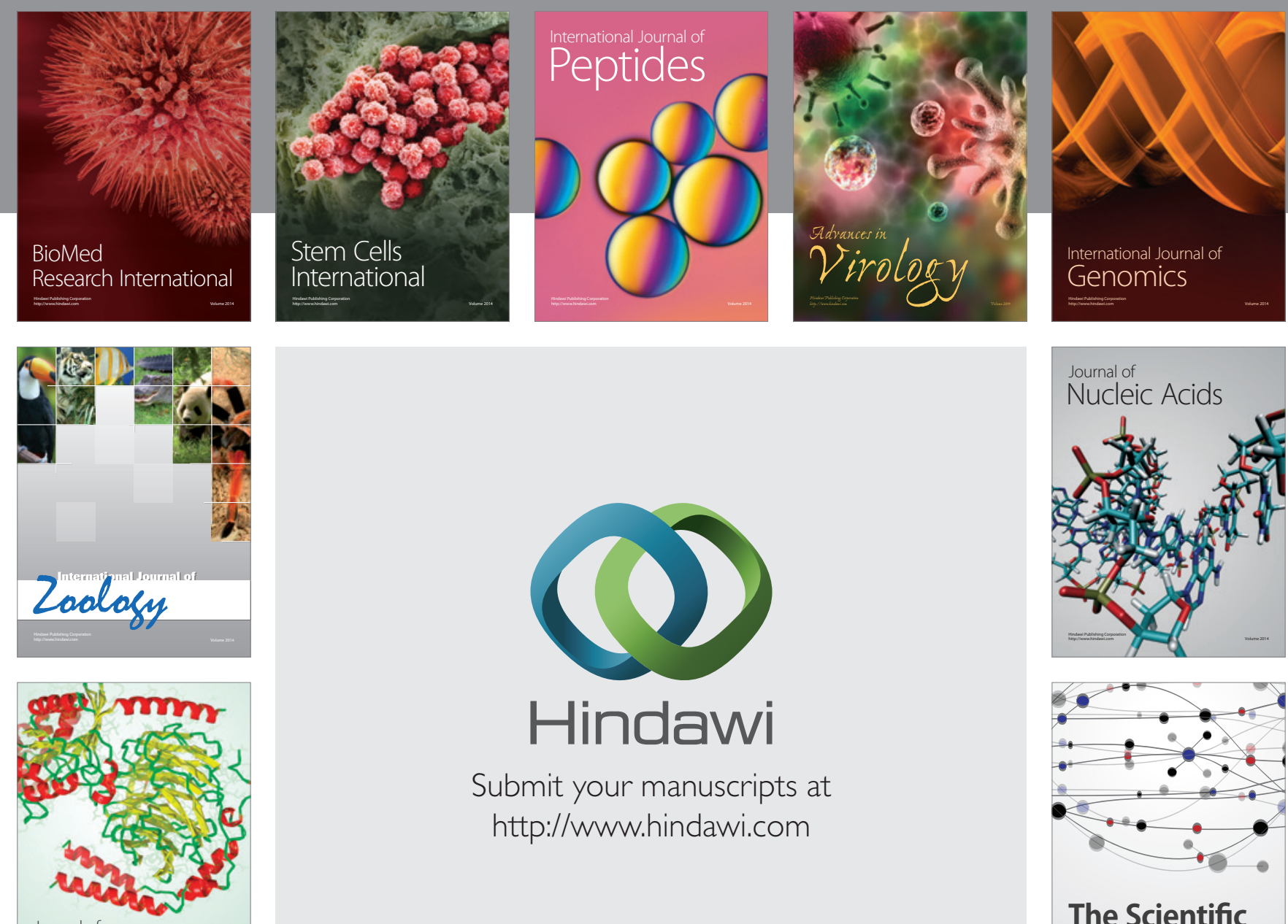

Submit your manuscripts at

http://www.hindawi.com

Journal of
Signal Transduction
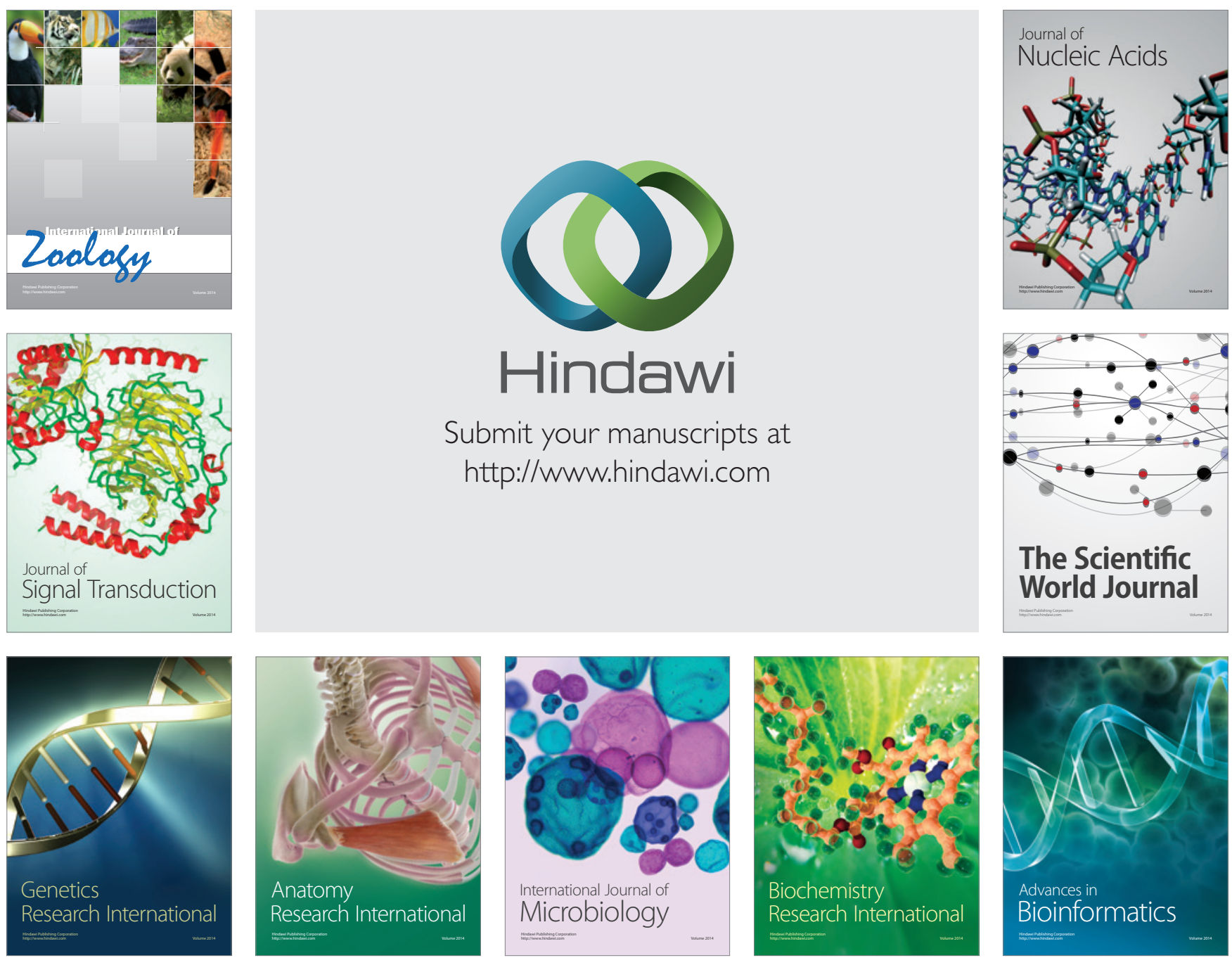

The Scientific World Journal
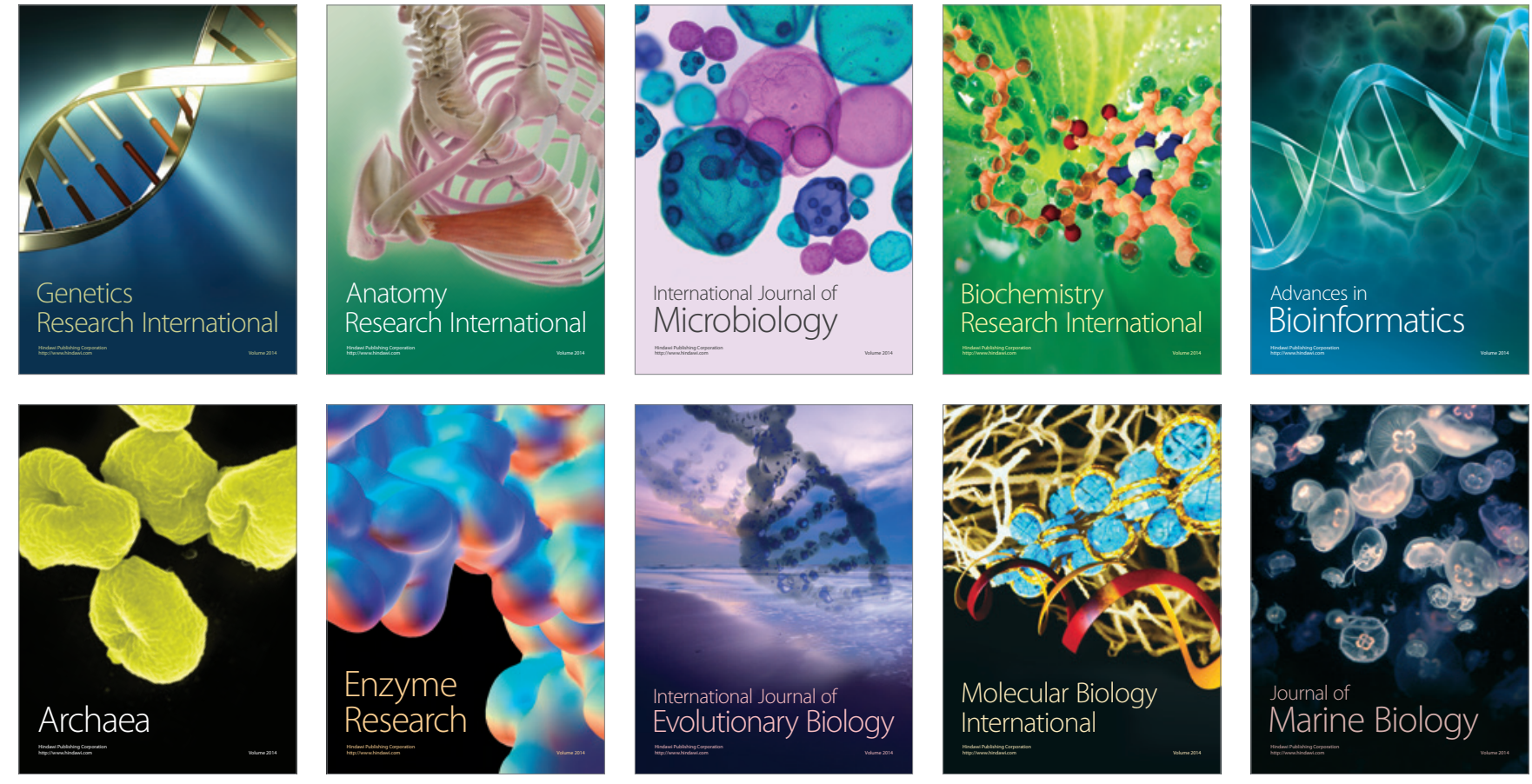